\title{
Management of Glomerulonephritis through Ayurveda - A Case report
}

\author{
Case Report
}

\section{Prajkta Anil Hagone $^{1^{*}}$, Vaishali Kuchewar ${ }^{2}$}

1. PG scholar, 2. Professor,

Department of Kayachikitsa, Mahatma Gandhi Ayurvedic College, Salod (H), Maharashtra, India

\begin{abstract}
Glomerulonephritis refers to an inflammation of the glomerulus, which is the unit involved in filtration in the kidney. Prompt diagnosis of glomerulonephritis is vital as it may rapidly lose kidney function if not treated urgently.it may present with isolated hematuria and or proteinuria.The incidence of GN varies between 0.2 to 2.5 per 100000 per year. It is a case of Glomerulonephritis which is correlated with Ushnavata. A patient 35 year old presented in the Kayachikitsa OPD with complaints of brown color urination, with burning and frequent micturition. She was also a known case of rheumatoid arthritis since 10 years. After clinical examination she was treated with oral medication (Gokshuradi Guggul and Neeri KFT) for 7 days. She had complete relief and no recurrence up to the month of August 2019.
\end{abstract}

Keywords: Ushnavata, GoshuradiGuggul, Hematuria, Proteinuria .

\section{Introduction}

Glomerulonephritis (GN) refers to an inflammation of the glomerulus, which is the unit involved in filtration in the kidney. This inflammation typically results in one or both of the nephrotic or nephritic syndromes.(1)It may present with isolated hematuria and or proteinuria (blood or protein in the urine); or as a nephrotic syndrome, a nephritic syndrome, acute kidney injury, or disease. In primary GN, disease is almost entirely restricted to the kidneys (as in IgA nephropathy or poststreptococcal GN) while in secondary GN it occurs in association with more diffuse inflammation (as in systemic lupus erythematosus or systemic vasculitis). Prompt diagnosis of GN is vital as it may rapidly lose kidney function if not treated urgently. (2) In modern medicine, Antibiotics are advice to prevent streptococcal infection (Prophylaxis).Steroids to suppress immunity. The incidence of GN varies between 0.2 to 2.5 per 100000 per year.(3)

In Ayurveda, GN can be correlated with Ushnavata which is one of the types of mutraghata because of similarity in clinical features which is having symptoms like raktayuktamutra(Hematuria), bastishool(pain in bladder) and daha(Burning sensation).(4)

\section{Case report}

A 35 years old female came to kayachikitsa OPD (OPD NO - 1904290056) on 29/04/2019 with the complaints of brown color urination, with burning and

*Corresponding Author:

Prajkta Anil Hagone,

Department of Kayachikitsa

Mahatma Gandhi Ayurvedic College,

Salod $(\mathrm{H})$, Wardha, Maharashtra

Email: P6hagone@gmail.com frequent micturition since 4 days. She had also Pain in lower abdomen. She was a known case of Rheumatoid Arthritis.

On examination, she was febrile (100OF), BP $120 / 70 \mathrm{mmHg}$, Pulse was $80 / \mathrm{min}$ and regular. Abdominal examination showed tenderness (1+) at hypo gastric region.

Table no. 1: Urine Investigation done on 29/4/2019

\begin{tabular}{|c|c|c|}
\hline Sr no. & Investigation & Findings \\
\hline 1 & Urine albumin & ++++ \\
\hline 2 & Urine sugar & Absent \\
\hline 3 & Pus cells & Occasional \\
\hline 4 & RBC & Plenty \\
\hline 5 & Epithelial cells & Occasional \\
\hline 6 & Motile bacilli & Seen \\
\hline
\end{tabular}

According to the clinical features, and urine investigation (table no 1), she was diagnosed as a case of acute Glomerulonephritis. Following treatment(table no. 2) was given in considering it as Ushnavata.

Table no 2: Treatment

\begin{tabular}{|l|l|l|l|l|}
\hline $\begin{array}{l}\text { Sr } \\
\text { no. }\end{array}$ & $\begin{array}{l}\text { Name of } \\
\text { drug }\end{array}$ & Dose & $\begin{array}{l}\text { Frequency } \\
\text { and } \\
\text { anupana }\end{array}$ & Duration \\
\hline 1 & $\begin{array}{l}\text { Gokshur } \\
\text { adi } \\
\text { Guggul } \\
(5)\end{array}$ & $500 \mathrm{mg}$ & $\begin{array}{l}\text { Thrice a } \\
\text { day with } \\
\text { water }\end{array}$ & 7 days \\
\hline 2 & $\begin{array}{l}\text { Syp } \\
\text { Neeri } \\
\text { KFT } \\
\text { (Aimil } \\
\text { pharma) }\end{array}$ & $15 \mathrm{ml}$ & $\begin{array}{l}\text { Thrice a } \\
\text { day with } \\
\text { water }\end{array}$ & 7 days \\
\hline
\end{tabular}




\section{Observation and result}

On the follow up after 7 days she had no fever, abdominal pain was decreased, and the micturition was normal. (Table no 3)

Table no. 3 The urine investigation showed following findings

\begin{tabular}{|c|l|l|l|}
\hline $\begin{array}{c}\text { Sr } \\
\text { no. }\end{array}$ & Investigation & $\begin{array}{c}\text { Before } \\
\text { treatment } \\
\mathbf{2 9 / 4 / 2 0 1 9}\end{array}$ & $\begin{array}{c}\text { After } \\
\text { treatment } \\
\mathbf{5 / 5 / 2 0 1 9}\end{array}$ \\
\hline 1 & $\begin{array}{l}\text { Urine } \\
\text { albumin }\end{array}$ & +++ & Absent \\
\hline 2 & Urine sugar & Absent & Absent \\
\hline 3 & Pus cells & Occasional & $1-3 /$ HPF \\
\hline 4 & RBC & Plenty & $0-2 / \mathrm{HPF}$ \\
\hline 5 & $\begin{array}{l}\text { Epithelial } \\
\text { cells }\end{array}$ & Occasional & $0-1 / \mathrm{HPF}$ \\
\hline 6 & Motile bacilli & Seen & Not seen \\
\hline
\end{tabular}

\section{Discussion}

According to Ayurveda Glomerulonephritis can be considered as a disease of mutravahastrotas. The features of this patient indicates involvement of vata and pitta dosha, the treatment was planned as per the principle of Ayurveda described for Ushnavata (6)

Gokshuradi Guggul is indicated in adhogataraktapitta, mutrakruccha, mutraghat , pakwashayagata vata, and udavarta. It contains gokshur, guggul, trikatu, triphala, musta. Gokshur is having madhur rasa, madhurvipak, sheet virya and snigdha guna \& bastishodhan property. (7) Due to these properties, burning sensation may be alleviated. It contains large quantity of nitrates and essential oil which act as diuretic(8). As GN is autoimmune disease gokshur may help in correcting immune system because of its .immunomodulatory effect (9). Methanolic extract of fruit of gokshur having antibacterial activity against gram positive and gram negative bacteria(10), the other contents of gokshuradi guggul like Triphala is having anti inflammatory and anti arthritic effect(11),and antibacterial activity(12), it is also having antipyretic property (13), Trikatu has Antioxidant(14), Antimicrobial( $15,16,17), \quad$ Analgesic(18), immunomodulatory $(19,20)$, and anti-inflammatory property $(21,22)$.

Neeri KFT contains punarnava (Boerhavia diffusa), gokshur (Tribulus terrestris), panchtrinmoola, varuna (Crataeva nurvala). all these drugs act as mutraldravya, ushir(Vetiveria zizanioides), rakta chandan (Pterocarpus santalinus), kakri beeja(Cucumis sativus), dhanyak (Coriandrum sativum), palashpushpa (Butea monosperma) having madhur rasa sheeta virya which are helpful to subside the burning micturition, In the study conducted by Manish Kr et al. Neeri KFT is found to be nephroprotective. The nephroprotective potential of Neeri-KFT might be due to the presence of several active constituents like glycosides, steroids, alkaloids, tannins, proteins, flavonoids, terenoids and carbohydrates as qualitatively estimated by preliminary phytochemical screening $(23)$

\section{Conclusion}

From this study it can be concluded that Glomerulonephritis can be successfully treated with appropriatete Aurvedic medication.

\section{References}

1. Nicki R, Colledge, Walker, Brian R.; Ralston, Davidson's principles and practice of medicine. illust. 21st edition, 2010,ch 17 p .500.

2. CS VinnDB Goliveira Acute gomerulonephritis, BMJ journal postgraduate, Medical journal volume 79, Issue 930

3. Division of nephrology, Department of Medicine, Beth Israel Deaconess Medical Center, Harvard Medical School, Boston, MA, USA

4. Murthy K R S editor, Madhav nidan, Choukhamba Orientalia, Varanasi. Mutraghat ch. P. 15,16

5. Shah N., Bharat Bhaishajya Ratnakar 2nd edition P B Jain publications, New Delhi, part 2, p 43.

6. Murthy K R S editor, Madhav nidan, Choukhamba Orientalia,Varanasi. Mutraghat ch. P. 15,16

7. Deshpande A.P., Dravyaguna Vijnyana, Proficient Publication House, Pune,Edition 2007 p. 308

8. Al-Ali M, Wahbi S, Twaij H, Al-Badr A, Tribulusterresris: Preliminary study of its diuretic and contractile effects and comparison with Zea mays. J Ethnopharmacol. 2003;85:257-60

9. Tiwari A,Shukla NP, Devi U. Effect of five medicinal plants use in Indian system of medicines on immune function in wistar rats.Afr JBiotechnol. 2011;10: 16637-45.

10. Al-Bayati FA, Al-Mola HF. Antibacterial and antifungal activities of different parts of Tribulus terrestris L. Growing in Iraq. J Zhejiang Univ Sci B 2008;9:154-9)

11. Rasool M, Sabina EP. Anti inflammatory effect of the Indian Ayurvedic herbal formulation riphala on adjuvant -induced arthritis in mice. Phytother Res 2007:21: 89-94 htp://dx.doi.org/10.1002/ptr.2183 PMid: 17533629

12. Srikumar R, Parthasarathy NJ, Shankar EM, Manikandan S, Vijayakumar R, Thangaraj R et al. Evalution of the growth inhibitory activity of Triphala against commom bacterial isolates from HIV infected patints .phytother Res 2007; 21 :476-80. htp://dx.doi.org/10.1002/ptr.2105 PMid:17273983

13. Rasool M, Sabina EP. Anti inflammatory effect of the Indian Ayurvedic herbal formulation riphala on adjuvant -induced arthritis in mice.Phytother Res 2007:21: 89-94 htp://dx.doi.org/10.1002/ptr.2183 PMid: 17533629

14. Jain N, Mishra, R.N. Antioxidant activity of trikatumega Ext. Int J Res Pharm Biomed Sci 2011;2:624-28,

15. Tambekar DH, Dahikar, S.B. Antibacterial potential of some herbal preparation: An alternative medicine in treatment of enteric bacterial infection. Int J Pharm PharmSci 2010;2: 176-9.

16. Dahikar SB, Bhutada SA, Vibhute SK, Sonvale VC, Tambekar DH, Kasture SB. Evaluation of antibacterial potential of trikatuchurna and its ingredients: An in vitro study. Int J Phytomed 2010; 2: 412-7. 
17. Reddy BU, Seetharam YN. Antimicrobial and analgesic activities of trikatuchurna and its ingredients.Pharmacol Online 2009;3:489-95,

18. Reddy BU, Seetharam YN. Antimicrobial and analgesic activities of trikatuchurna and its ingredients.Pharmacol Online 2009;3:489-95

19. Malvankar PR. Anthelmintic activity of water extracts of trikatuchurna and its individual ingredients on Indian earthworms. Int J Pharm Bio Sci 2012;3:374-8.

20. Jain N, Mishra RN. Immunomodulator activity of trikatu mega ext. Int $\mathrm{J}$ Res Pharm Biomed Sci 2011;2: 160-64.
21. Sabina EP, Nagar S, Rasool M. A role of piperine on monosodium urate crystal-induced inflammation - An experimental model of gouty arthritis, inflammation isoniazid in rabbits.Ind $\mathrm{J}$ Pharmacol 2008;30: 254-6.

22. Ghodake PB, Dhavan K, Gazi S, Patil SM. Potentiation of anti-inflammatory activity of Rasna by Trikatu. Deccan J Nat Prod 2010;1: 210-15.

23. Manish Kr. Tiwari et al. Nephroprotective role of neeri-kft (a polyherbal formulation) against gentamicin induced nephrotoxicity in experimental rat model: a pre-clinical study EJPMR, 2016,3(8), 410-417. 